\title{
MARKERS OF INFLAMMATION AND HEALTH-RELATED FITNESS AMONG POLISH OVERWEIGHT AND OBESE ADOLESCENTS
}

\author{
MARKERY STANU ZAPALNEGO I JAKOŚĆ ŻYCIA ZWIĄZANA ZE ZDROWIEM WŚRÓD \\ POLSKIEJ MŁODZIEŻY Z NADWAGĄ I OTY€OŚCIĄ
}

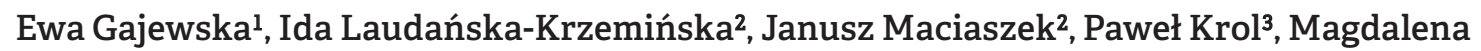
Sobieska ${ }^{4}$

'Department of Developmental Neurology, Poznan University of Medical Sciences, Poland. 2Department of Physical Activity Study and Health Promotion, Poznan University School of Physical Education, Poland

${ }^{3}$ Pediatric Surgery and Urology Clinic, Neurourology Unit, Poznan, Poland

4 Department of Physiotherapy and Rehabilitation, Poznan University of Medical Sciences, Poland.

ABSTRACT

\section{Background}

Obesity is considered as one of the risk factors for heart disease, cancer, diabetes, greater rates of mortality as young adults.

\section{Objectives}

Body composition affects physical fitness, but no relation to sex and the degree of obesity was investigated so far in Polish adolescents.

\section{Material and methods}

The studies involved 118 adolescents (12 to 18 years old) who were overweight or obese. The assessment of the body composition was performed by measuring the bioimpedance. The concentration of alphal-acid glycoprotein and alphal-antichymotrypsin was measured by immunoelectrophoresis. The glycosylation profiles of AGP and ACT were investigated by crossed-affinity immunoelectrophoresis with Concanavalin A. Physical fitness was measured using the Eurofit test.

\section{Results}

In the study group of girls the body fat content determined on the basis of bioimpedance is not significantly different for overweight and obesity, whereas in the group of boys it is significantly higher in obese individuals. Fitness tests showed a heterogeneous impact of obesity on fitness: some results of the tests were good (FLB, PLT, SAR, HGR) in other tests (SBJ, SUP, BAH, ESR, SHR) the results were considerably inferior. The study of acute phase proteins showed elevated levels of AGP, higher in boys, lower reactivity with ConA in overweight boys and girls, and higher reactivity with ConA in obese boys and girls.

\section{Conclusion}

As the BMI percentile, waist circumference and waist-to-height ratio increase, the results of fitness tests, measured using the EUROFIT test, deteriorate. The consequences of excessive 
body fat are greater for boys, both in terms of abnormal laboratory markers and physical fitness.

Keywords: bioimpedance, obesity, inflammation, fitness

\section{STRESZCZENIE}

Otyłość jest uważana za jeden z czynników ryzyka chorób serca, raka, cukrzycy oraz większej śmiertelności u dorosłych w młodym wieku.

\section{Cel}

Skład ciała wpływa na sprawność fizyczną, ale dotychczas nie badano związku z płcią i stopniem otyłości u polskiej młodzieży.

\section{Materiał i metoda}

Badaniami objęto 118 nastolatków (w wieku od 12 do 18 lat) z nadwagą lub otyłością. Oceny składu ciała dokonano poprzez pomiar bioimpedancji elektrycznej. Stężenie alfal- kwaśnej glikoproteiny i alfa- antychymotrypsyny mierzono metodą immunoelektroforezy. Profile glikozylacji AGP i ACT badano za pomocą immunoelektroforezy krzyżowego powinowactwa z konkanawaliną A. Sprawność fizyczną mierzono za pomocą testu Eurofit.

\section{Wyniki}

W badanej grupie dziewcząt zawartość tkanki tłuszczowej określona na podstawie bioimpedancji nie różni się istotnie dla osób z nadwagą i otyłoścą, natomiast w grupie chłopców była istotnie wyższa u osób otyłych. Testy sprawności wykazały niejednorodny wpływ otyłości na sprawność: niektóre wyniki testów były dobre (FLB, PLT, SAR, HGR), w innych (SBJ, SUP, BAH, ESR, SHR) wyniki były znacznie gorsze. Badania białek ostrej fazy wykazały podwyższone stężenie AGP, wyższe u chłopców, zmniejszoną aktywność z ConA u nastolatków z nadwagą i podwyższoną u osób otyłych.

\section{Wniosek}

Wraz ze wzrostem percentyla BMI, obwodu talii i stosunku talii do wzrostu wyniki testów sprawności mierzonych testem EUROFIT pogarszają się. Konsekwencje nadmiernej tkanki tłuszczowej są większe u chłopców, zarówno nieprawidłowych wskaźników laboratoryjnych, jak i sprawności fizycznej.

Słowa kluczowe: bioimpedancja, otyłość, stan zapalny, sprawność

\section{Introduction}

The consequences of childhood and adolescent obesity include earlier puberty and menarche in girls, type 2 diabetes and increased incidence of the metabolic syndrome in youth and adults, and obesity in adulthood (Biro and Wien, 2010). Obesity is considered as one of the risk factors for heart disease, cancer, diabetes, greater rates of mortality as young adults (Engeland et al., 2004). Obesity is likely the result of complex interactions among genes, dietary intake, physical activity, and the environment factors (Ben-Sefer et al., 2009).

The parameters of body composition such as the level of body fat, muscle mass hydration, are the predictors of such health indicators in young people as whole body bone mineral density (El Hage et al., 2011) and lipid 
concentrations (Lamb et al., 2011). Body fat percentage explained $2-20 \%$ of the variation in lipid concentrations, which suggests that body fat percentage is just one factor that influences lipid concentrations in youths (Lamb et al., 2011).

The health consequences described above are the subject of many analyses on the body composition in adolescents. Discussions are related to the relationships between the parameters of body composition and the body mass index (BMI) in adolescents. As Okorodudu and colleagues (2010) suggest commonly used BMI cutoff values to diagnose obesity have high specificity, but low sensitivity to identify adiposity, as they fail to identify half of the people with excess body fat percentage (Okorodudu et al., 2010).

Body composition also affects health-related fitness (HRF) (Bouchard et al., 1994). The issue of the impact of such parameters as the BMI and body fat on HRF has been mentioned in many studies (Pate et al. 1989, Maciaszek et al. 2001). Easy to use BMI should be applied with caution in scientific research in children and adolescents as the relationship between the BMI and fat tissue depends on age, sex, ethnicity and the level of fitness (Gallagher et al., 2010). Body composition variables, including total body fat mass and muscle mass are better measures of obesity than the BMI alone (Tarnoki et al., 2014). The methods that are increasingly being used for the assessment of body composition in humans include ultrasonography and methods based on bioelectrical impedance analysis (BIA) of various tissues of the human body (Jakicic et al., 1999).

The Eurofit Physical Fitness Test Battery (EUROFIT) is a test that is frequently used for the assessment of physical fitness elements related to health. EUROFIT allows to estimate a number of physical fitness elements, such as balance, speed, flexibility, strength (explosive, static, functional), agility, cardiorespiratory endurance. Scoring tables for this test in the form of percentile charts have been developed in Poland. These charts allow a detailed assessment of a given sample regardless of age or sex (Dobosz, 2012).

\section{Aim}

In this study we decided to analyze the relationship between the body composition in adolescents with overweight or obesity and laboratory markers of inflammation, as well as physical fitness as compared with the population results differentiated by sex.

\section{Materials and methods}

All procedures performed in studies involving human participants were in accordance with the ethical standards of the institutional and/or national research committee and with the 1964 Helsinki declaration and its later amendments or comparable ethical standards.

Informed consent: Informed consent was obtained from all individual participants included in the study.

The studies involved 118 adolescents, aged from 12 to 18 years who were overweight or obese. For each participant BMI was calculated according to the formula: (weight/ height ${ }^{2} ; \mathrm{kg} / \mathrm{m}^{2}$ ). Participants were considered overweight or obese based on age specific BMI percentile curves at the appropriate age (Dobosz, 2012).

Weight was measured to $0.1 \mathrm{~kg}$ on a certified electronic scale (Tanita electronic scale BWB-800 MA (Wunder SA.BI. Srl), with the participants in sports clothing, no shoes. Height to $0.01 \mathrm{~m}$ was measured with a stadiometer (Holtain Ltd., Crymych, Pembs). The following circumferences were measured using a non-stretchable measuring tape: waist circumference (WC), hip circumference (HC). The investigated group was divided according to sex and according to BMI percentiles into categories overweight or obese (Table 1). The following indices have also been calculated: waist-to-hip ratio (WHR) and waist-to height ratio (WHtR).

The assessment of the body composition was performed by measuring the bioimpedance using a body composition bioanalyzer 
by Akern RJL system - BIA 101/S. The measurement was based on measuring the impedance of the human body to a current with a frequency of $50 \mathrm{kHz}$. The obtained results (resistance and reactance), supplemented by data on: age, sex, height and body weight of the subjects allow for an assessment using the software supplied with the device for individual components of the body composition, that is: the content of lean body tissue LEAN\% and the content of fat tissue -FAT\%. The estimates obtained come from proprietary algorithms of the manufacturer. Taking into account these individual features increases the reliability of the BIA measurement and provides data comparable to those obtained by the DEXA method. The results of the body composition components are presented in units of weight $(\mathrm{kg})$ and as a percentage of total body weight (\%). All measurements were performed in the morning in the fasting state, after voiding bladder, in the supine position. A person subject to the examination lay on a non-conducting surface. Electrodes were placed on the dorsal side at the base of the hand (1. electrode) and at the base of the fingers (2. electrode) and on the dorsal side at the base of the foot (3. electrode) and at the base of the toes (4. electrode), always on the right side of the body. The areas of electrode placement had been properly cleaned previously. The analysis of body composition using bioimpedance is precise enough to determine body composition and it is recommended for epidemiological purposes (Tompuri et al. 2015).

Physical examination excluded all symptoms of on-going infection or inflammation of any origin. From all participants a blood sample was obtained for routine laboratory measurements and serum was separated in a routine way and frozen until investigation. The concentration of acute phase proteins: alphal-acid glycoprotein (AGP); and alphalantichymotrypsin (ACT) was measured by immunoelectrophoresis according to Laurell (Laurell 1966). Antibodies and standard solutions were bought from DakoCytomation. (Denmark). The glycosylation profiles of AGP and ACT were investigated by crossed-affinity immunoelectrophoresis with Concanavalin A. Reference values for acute-phase proteins in children were established earlier in the same laboratory, using the same methods. Normal serum values for AGP and ACT were shown as $800 \pm 100 \mathrm{mg} / \mathrm{L}$ and $400 \pm 50 \mathrm{mg} / \mathrm{L}$, respectively (Pawlaczyk et al., 2001).

In all investigated children on-going inflammatory processes and allergic background were excluded by ear-nose-throat allergology specialist.

Physical fitness was measured using the Eurofit test which consists of: flamingo balance (FLB - balance), plate tapping (PLT - coordination and speed), sit-and reach (SAR - flexibility), standing broad jump (SBJ - explosive strength), handgrip (HGR - static strength), sit-ups (SUP - trunk strength and endurance), bent-arm hang (BAH - upper body strength and endurance) and shuttle run $10 \times 5 \mathrm{~m}$ (SHRspeed and agility), $20 \mathrm{~m}$ endurance shuttle run (ESR - cardio-respiratory endurance) [17]. For each participant, his or her result was expressed as percentile of population results presented by Dobosz (Dobosz, 2012).

The reference values for waist circumference were based on data presented by Kułaga et al. The upper reference limit was the value of the 90th percentile, for boys and girls respectively. The detailed data is presented in Table 1.

The content of fat tissue (FAT\%) was investigated in Polish teenagers by Stupnicki 2015. The range corresponding to the study group is within the age range from 12 to 18 and is as follows: 12 years for girls - Me 18 (17-19) and 18 years - Me 20 (18.5-21); 12 years for boys - Me 17 (15-18) and 18 years - Me 18.5 (17-20). The reference values for hydration were used following [20] : boys 12-18 years $52 \%-66 \%$, girls $12-18$ years $-49 \%-63 \%$.

\section{Statistical analysis}

The description of the investigated variables was performed using medians and quartiles. The comparison of the investigated subgroups was performed by means of the 
U Mann-Whitney or ANOVA, respectively. The correlations were calculated using the Spearman test. The Statistica 10.0. software was used for this purpose.

\section{Results}

The boys and girls participating in the study did not differ significantly in routine laboratory measurements. The concentration of HDL cholesterol was significantly higher in all of the studied teenagers and its percentage was definitely lower than the reference values. The concentration of LDL cholesterol in boys was not significantly higher. They had a significantly higher percentage of dry mass and water, and the percentage of fat tissue was lower than in girls. Highly elevated levels of LDL and the reduced percentage of HDL\% indicate lipid metabolism disorders. The body fat content, also measured using the bioimpedance method, was higher in the study group than the population standards (Altman et al., 1961). It was accompanied by significantly greater waist circumference than recommended. The BIA analysis of body composition showed a considerably higher level of fat than the reference values and a lower level of hydration and the deterioration of the indicators as the BMI increased. The body fat content determined on the basis of BIA differed between overweight and obese girls or boys, but also between overweight boys and girls and obese boys and girls, respectively.

The analysis of the results of fitness tests showed a heterogeneous impact of obesity on fitness: some results of the tests included in the EUROFIT for the subjects were good (FLB, PLT, SAR), in terms of the upper percentile values for the Polish population. However, in other tests (SBJ, SUP, BAH, ESR, SHR) the results were considerably inferior. The detailed data is presented in Table 2. The results of SBJ and SHR tests were significantly worse in comparison to the population percentiles for the subgroups with obesity.

The study of acute phase proteins as markers of systemic inflammation process showed elevated levels of AGP, higher in boys, and a different glycosylation profile: changed towards lower reactivity with ConA (so-called chronic inflammatory profile, Pawlaczyk et al., 2001) in overweight boys and girls, and clearly "acute profile" (higher reactivity with ConA) in obese boys and girls, with an evident additional W3 variant absent in healthy subjects. This difference was statistically significant. Antichymotrypsin concentration was higher in boys and its glycosylation profile also showed characteristics of acute inflammation (with a clearly higher percentage of the A5 variant absent in healthy individuals). This tendency was less expressed in girls. The detailed data is presented in Table 3.

The analysis of the correlation between the results of anthropometric studies and the parameters of body composition and the results of fitness tests showed that with the increase of the BMI percentile, waist circumference and WHtR, the results of fitness tests (SBJ, SUP, ESR and SAR) deteriorate. However, the basis for this seems to be more biomechanical rather than metabolic. When it comes to the relationship between the results of laboratory tests, studies of acute phase proteins with the results of fitness tests, single correlations were found between the percentages of differently glycosylated variants of acute phase proteins and the results of the fitness tests, which generally proved to be good (PLT and $\mathrm{SAR}$ ). It can be suggested that the closer the results of glycosylation were to normal, the better the test results (Table 4).

\section{Discussion}

Many observations show that obese children often move awkwardly, their movements are not very precise, and they lack the basic motor skills. However, it has been observed that the degree of reduced physical fitness of obese children is related to sex. Lafortuna point to a sex-dependent pattern of the variability of body composition among obese individuals, which may be an important determinant of varying mobility limitations and differences related to physical fitness in girls and boys. In other studies the same researchers showed 
Table. 1 Routine laboratory results and demographic parameters for the whole group and for the subgroups divided according to sex and categories of BMI percentiles (overweight/obesity). The difference between the groups was investigated, using, $\mathrm{U}$ Mann-Whitney test, $\mathrm{p}$ value is given if the difference was statistically significant. Reference values came from the laboratory that performed the measurements.

\begin{tabular}{|c|c|c|c|c|c|c|c|c|c|c|}
\hline \multirow[b]{2}{*}{ 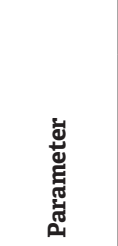 } & \multirow[b]{2}{*}{ 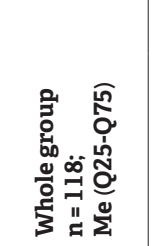 } & \multirow[b]{2}{*}{ 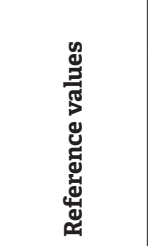 } & \multicolumn{2}{|l|}{ Boys, $n=58$} & \multirow{2}{*}{ 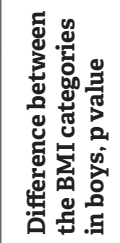 } & \multicolumn{2}{|l|}{ Girls, $n=60$} & \multirow{2}{*}{ 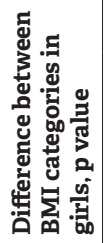 } & \multirow{2}{*}{ 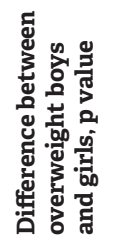 } & \multirow{2}{*}{ 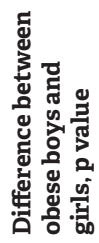 } \\
\hline & & & 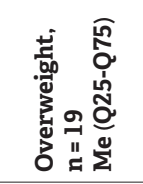 & 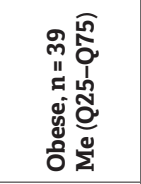 & & 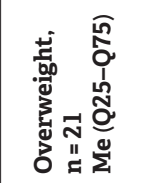 & 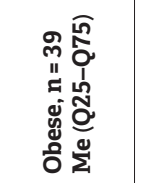 & & & \\
\hline $\begin{array}{l}\text { GLU } \\
\mathrm{mmol} / \mathrm{L}\end{array}$ & $\begin{array}{l}4.2 \\
(4.0-4.5)\end{array}$ & $3.9-6.4$ & $\begin{array}{l}4.2 \\
(3.9-4.4)\end{array}$ & $\begin{array}{l}4.2 \\
(3.9-4.5)\end{array}$ & - & $\begin{array}{l}4.0 \\
(3.7-4.6)\end{array}$ & $\begin{array}{l}4.3 \\
(4.1-4.4)\end{array}$ & - & - & - \\
\hline $\begin{array}{l}\text { CHOL } \\
\mathrm{mmol} / \mathrm{L}\end{array}$ & $\begin{array}{l}4.2 \\
(3.6-4.7)\end{array}$ & $<5.2$ & $\begin{array}{l}4.8 \\
(4.0-5.5)\end{array}$ & $\begin{array}{l}4.3 \\
(3.6-4.8)\end{array}$ & - & $\begin{array}{l}4.0 \\
(3.7-4.2)\end{array}$ & $\begin{array}{l}4.2 \\
(3.6-4.5)\end{array}$ & - & - & - \\
\hline $\begin{array}{l}\mathrm{TG} \\
\mathrm{mmol} / \mathrm{L}\end{array}$ & $\begin{array}{l}1.1 \\
(0.9-1.4)\end{array}$ & $0.55-2.3$ & $\begin{array}{l}1.2 \\
(1.0-1.4)\end{array}$ & $\begin{array}{l}1.2 \\
(1.0-1.4)\end{array}$ & - & $\begin{array}{l}1.3 \\
(0.7-1.5)\end{array}$ & $\begin{array}{l}1.0 \\
(0.8-1.3)\end{array}$ & - & - & - \\
\hline $\begin{array}{l}\mathrm{LDL} \\
\mathrm{mmol} / \mathrm{L}\end{array}$ & $\begin{array}{l}26.4 \\
(18.2-32.3)\end{array}$ & $<3.5$ & $\begin{array}{l}25.8 \\
(23.4-26.5)\end{array}$ & $\begin{array}{l}29.9 \\
(22.6-34.6)\end{array}$ & - & $\begin{array}{l}2.9 \\
(2.8-3.2)\end{array}$ & $\begin{array}{l}23.1 \\
(3.0-31.5)\end{array}$ & - & - & - \\
\hline HDL & $\begin{array}{l}2.7 \\
(1.6-3.0)\end{array}$ & $\begin{array}{l}\text { Girls } \\
1.0-2.1 \\
\text { Boys } \\
0.9-1.8\end{array}$ & $\begin{array}{l}3.4 \\
(2.8-3.9)\end{array}$ & $\begin{array}{l}2.9 \\
(2.1-3.3)\end{array}$ & - & $\begin{array}{l}1.6 \\
(1.3-2.7)\end{array}$ & $\begin{array}{l}2.3 \\
(1.5-3.0)\end{array}$ & - & - & - \\
\hline HDL\% & $\begin{array}{l}0.8 \\
(0.7-1-7)\end{array}$ & $>30$ & $\begin{array}{l}0.9 \\
(0.7-1.1)\end{array}$ & $\begin{array}{l}0.9 \\
(0.5-1.5)\end{array}$ & - & $\begin{array}{l}1.1 \\
(0.8-31.3)\end{array}$ & $\begin{array}{l}0.8 \\
(0.8-27.3)\end{array}$ & - & - & - \\
\hline FAT\% & $\begin{array}{l}30.9 \\
(26.0-37.6)\end{array}$ & $\begin{array}{l}\text { Girls: } \\
18-25 \\
\text { Boys: } \\
12-18\end{array}$ & $\begin{array}{l}17.5 \\
(16.8-19.4)\end{array}$ & $\begin{array}{l}27.5 \\
(24.6-31.1)\end{array}$ & 0.001 & $\begin{array}{l}30.7 \\
(29.2-34.6)\end{array}$ & \begin{tabular}{|l|}
37.7 \\
$(34.3-40.7)$
\end{tabular} & 0.003 & 0.000 & 0.000 \\
\hline LEAN\% & $\begin{array}{l}69.0 \\
(62.4-74.0)\end{array}$ & & $\begin{array}{l}82.5 \\
(80.6-83.2)\end{array}$ & $\begin{array}{l}72.5 \\
(68.0-75.4)\end{array}$ & 0.001 & $\begin{array}{l}69.3 \\
(65.4-70.8)\end{array}$ & $\begin{array}{l}62.2 \\
(59.3-65.7)\end{array}$ & - & 0.000 & 0.000 \\
\hline WATER\% & $\begin{array}{l}45.2 \\
(42.3-48.1)\end{array}$ & $\begin{array}{l}\text { Girls: } \\
\text { 49-63 } \\
\text { Boys: } \\
\text { 52-66 }\end{array}$ & $\begin{array}{l}53.8 \\
(51.7-56.0)\end{array}$ & $\begin{array}{l}47.0 \\
(45.0-48.9)\end{array}$ & 0.001 & $\begin{array}{l}45.2 \\
(44.0-46.4)\end{array}$ & $\begin{array}{l}42.4 \\
(40.1-43.9)\end{array}$ & 0.006 & 0.000 & 0.000 \\
\hline WC & $\begin{array}{l}102.0 \\
(96.0-113.0)\end{array}$ & $\begin{array}{l}\text { Girls: } \\
\text { 73-77 (90th } \\
\text { \%) } \\
\text { Boys: } \\
77-87.5 \\
\text { (90th \%) }\end{array}$ & $\begin{array}{l}97 \\
(93-101)\end{array}$ & $\begin{array}{l}109 \\
(101-119)\end{array}$ & - & $94(88-96)$ & $\begin{array}{l}102 \\
(98-110)\end{array}$ & 0.000 & - & 0.005 \\
\hline WHR & $\begin{array}{l}1.0 \\
(0.9-1.0)\end{array}$ & $\begin{array}{l}\text { Girls: }<0.85 \\
\text { Boys: } \\
<1.0\end{array}$ & $\begin{array}{l}0.98 \\
(0.97-1.01)\end{array}$ & $\begin{array}{l}1.0 \\
(0.9-1.1)\end{array}$ & - & $\begin{array}{l}0.9 \\
(0.8-0.9)\end{array}$ & $\begin{array}{l}0.9 \\
(0.9-1.0)\end{array}$ & 0.014 & 0.002 & 0.000 \\
\hline WHtR & $\begin{array}{l}0.62 \\
(0.57-0.66)\end{array}$ & $<0.5$ & $\begin{array}{l}0.6 \\
(0.6-0.6)\end{array}$ & $\begin{array}{l}0.6 \\
(0.6-0.7)\end{array}$ & - & $\begin{array}{l}0.5 \\
(0.5-0.6)\end{array}$ & $\begin{array}{l}0.6 \\
(0.6-0.7)\end{array}$ & - & - & - \\
\hline
\end{tabular}

that physical fitness of obese individuals is particularly at risk due to a large imbalance between the mass of elements performing movements, i.e. the muscles and the fat mass. In their studies on extremely obese individuals, the disproportions of the lean body mass as compared with the fat mass particularly affected physical fitness in women (Lafortuna et al., 2005).

According to the presented results, both sexes have more tissue located around the waist than suggested by the range of the reference values (Kułaga et al., 2008). The values for both sexes exceeded the limits of reference values to a similar extent; no differences in the type of obesity were found, which is confirmed by the analysis of the WHtR ratio.

The significant differences in the weakening of muscle strength in boys and girls in relation to the population found in our study seem to confirm the phenomenon described here. obese boys from the study group differed much more from their peers in the population (median SBJ $=2.1$ percentile and median $\mathrm{HGR}=43.9$ percentile) than obese girls from their peers (median SBJ $=7.3$ percentile and median HGR $=62.9$ percentile). Similar 
Table 2. Percentiles of particular EUROFIT tests for the whole group and for the subgroups divided according to sex and categories of BMI percentiles (overweight/obesity). The difference between the groups was investigated, using, U Mann-Whitney test, $p$ value is given if the difference was statistically significant. FLB - flamingo balance, PLT - plate tapping, SAR - sit-and reach, SBJ - standing broad jump, HGR - handgrip, SUP - sit-ups, BAH - bent-arm hang and SHR - shuttle run, ESR - endurance shuttle run.

\begin{tabular}{|c|c|c|c|c|c|c|c|c|c|}
\hline \multirow[b]{2}{*}{ 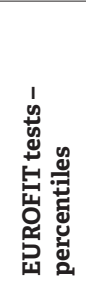 } & \multirow[b]{2}{*}{ 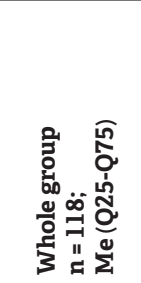 } & \multicolumn{2}{|l|}{ Boys, $n=58$} & \multirow{2}{*}{ 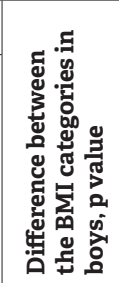 } & \multicolumn{2}{|l|}{ Girls, $n=60$} & \multirow{2}{*}{ 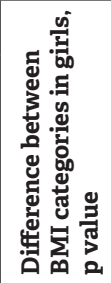 } & \multirow{2}{*}{ 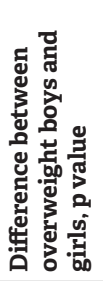 } & \multirow{2}{*}{ 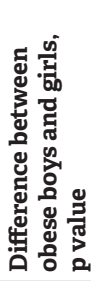 } \\
\hline & & 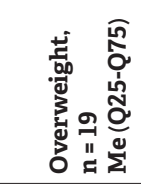 & 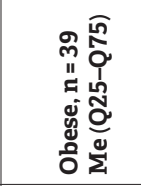 & & 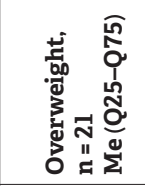 & 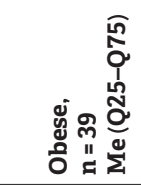 & & & \\
\hline FLB & $\begin{array}{l}96.8 \\
(89.4-97.9)\end{array}$ & $\begin{array}{l}97.5 \\
(87.8-99.7)\end{array}$ & $\begin{array}{l}97.7 \\
(87.8-97.8)\end{array}$ & - & $\begin{array}{l}96.9 \\
(95.9-97.0)\end{array}$ & $\begin{array}{l}96.5 \\
(84.5-96.8)\end{array}$ & 0.014 & - & 0.002 \\
\hline PLT & $\begin{array}{l}82.9 \\
(54.8-97.1)\end{array}$ & $\begin{array}{l}11.1 \\
(4.9-15.8)\end{array}$ & $\begin{array}{l}22.6 \\
(2.5-47.4)\end{array}$ & - & $\begin{array}{l}30.4 \\
(2.3-65.1)\end{array}$ & $\begin{array}{l}16.5 \\
(3.0-42.3)\end{array}$ & - & - & - \\
\hline SBJ & $\begin{array}{l}4.5 \\
(0.7-16.2)\end{array}$ & $\begin{array}{l}8.7 \\
(3.5-12.4)\end{array}$ & $\begin{array}{l}1.3 \\
(0.4-11.9)\end{array}$ & - & $\begin{array}{l}16.8 \\
(4.1-26.8)\end{array}$ & $\begin{array}{l}6.1 \\
(1.9-15.4)\end{array}$ & - & - & 0.030 \\
\hline HGR & $\begin{array}{l}52.6 \\
(29.0-75.6)\end{array}$ & $\begin{array}{l}9.4 \\
(6.3-32.3)\end{array}$ & $\begin{array}{l}52.5 \\
(22.0-76.8)\end{array}$ & 0.005 & $\begin{array}{l}66.9 \\
(49.6-72.8)\end{array}$ & $\begin{array}{l}62.7 \\
(35.8-76.6)\end{array}$ & - & 0.001 & - \\
\hline SUP & $\begin{array}{l}7.1 \\
(1.8-19.4)\end{array}$ & $\begin{array}{l}20.3 \\
(4.7-34.1)\end{array}$ & $\begin{array}{l}4.7 \\
(1.7-19.0)\end{array}$ & - & $\begin{array}{l}8.3 \\
(4.6-18.1)\end{array}$ & $\begin{array}{l}7.1 \\
(1.3-23.8)\end{array}$ & - & - & - \\
\hline $\mathrm{BAH}$ & $\begin{array}{l}13.6 \\
(6.9-30.9)\end{array}$ & $\begin{array}{l}9.2 \\
(6.0-11.2)\end{array}$ & $\begin{array}{l}11.6 \\
(4.4-33.8)\end{array}$ & - & $\begin{array}{l}17.4 \\
(11.6-37.6)\end{array}$ & $\begin{array}{l}24.6 \\
(16.0-32.2)\end{array}$ & - & - & - \\
\hline ESR & $\begin{array}{l}15.1 \\
(1.8-62.0)\end{array}$ & $\begin{array}{l}9.8 \\
(5.4-54.1)\end{array}$ & $\begin{array}{l}7.8 \\
(1.0-48.3)\end{array}$ & - & $\begin{array}{l}25.9 \\
(7.5-85.4)\end{array}$ & $\begin{array}{l}14.6 \\
(1.8-74.2)\end{array}$ & - & - & - \\
\hline SHR & $\begin{array}{l}5.7 \\
(1.7-13.6)\end{array}$ & $\begin{array}{l}5.7 \\
(2.8-10.5)\end{array}$ & $\begin{array}{l}3.7 \\
(1.4-12.8)\end{array}$ & - & $\begin{array}{l}11.7 \\
(3.1-27.2)\end{array}$ & $\begin{array}{l}5.7 \\
(0.9-13.0)\end{array}$ & 0.047 & - & - \\
\hline SAR & $\begin{array}{l}85.1 \\
(61.6-96.2)\end{array}$ & $\begin{array}{l}95.9 \\
(61.6-98.3)\end{array}$ & $\begin{array}{l}81.5 \\
(33.0-96.9)\end{array}$ & - & \begin{tabular}{|l|}
92.5 \\
$(74.9-97.8)$
\end{tabular} & $\begin{array}{l}87.2 \\
(70.0-94.2)\end{array}$ & - & - & - \\
\hline
\end{tabular}

Table 3. Acute phase proteins concentrations and percentages of distinctly glycosylated variants for the whole group and for the subgroups divided according to sex and categories of BMI percentiles (overweight/obesity). The difference between the groups was investigated, using, U Mann-Whitney test, $p$ value is given if the difference was statistically significant. AGP - acid glycoprotein; W0-W3 distinctly glycosylated variants; ACT - antichymotrypsin; Al-A5 - distinctly glycosylated variants.

\begin{tabular}{|c|c|c|c|c|c|c|c|c|c|c|}
\hline \multirow[b]{2}{*}{ 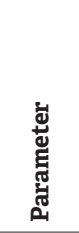 } & \multirow[b]{2}{*}{ 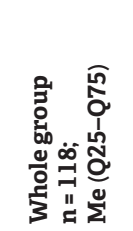 } & \multirow[b]{2}{*}{ 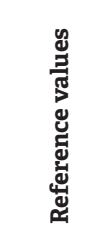 } & \multicolumn{2}{|l|}{ Boys, $n=58$} & \multirow[b]{2}{*}{ 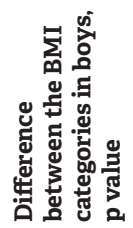 } & \multicolumn{2}{|l|}{ Girls, $n=60$} & \multirow[b]{2}{*}{ 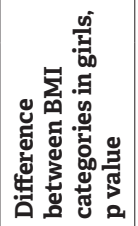 } & \multirow[b]{2}{*}{ 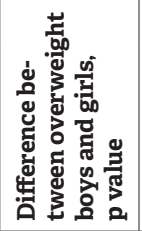 } & \multirow[b]{2}{*}{ 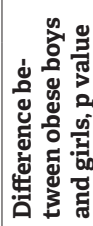 } \\
\hline & & & 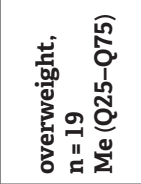 & 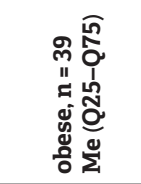 & & 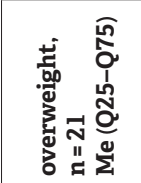 & 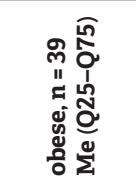 & & & \\
\hline $\begin{array}{l}\text { AGP- } \\
\text { mg/L }\end{array}$ & $\begin{array}{l}962 \\
(741-1309)\end{array}$ & $700-900$ & $\begin{array}{l}1027 \\
(693-1348)\end{array}$ & $\begin{array}{l}912 \\
(713-1001)\end{array}$ & - & $\begin{array}{l}856 \\
(528-1501)\end{array}$ & $\begin{array}{l}1078 \\
(770-1386)\end{array}$ & 0.047 & 0.044 & 0.045 \\
\hline W0-\% & \begin{tabular}{|l|}
43.1 \\
$(36.4-46.6)$
\end{tabular} & 43 & $\begin{array}{l}43.8 \\
(43.2-44.0)\end{array}$ & $\begin{array}{l}40.8 \\
(34.3-44.7)\end{array}$ & - & $\begin{array}{l}45.9 \\
(38.2-48.1)\end{array}$ & $\begin{array}{l}42.3 \\
(36.9-49.4)\end{array}$ & - & 0.037 & - \\
\hline Wl-\% & \begin{tabular}{|l|}
43.3 \\
$(40.4-46.7)$
\end{tabular} & 45 & $\begin{array}{l}42.5 \\
(41.0-47.5)\end{array}$ & $\begin{array}{l}44.6 \\
(40.5-46.2)\end{array}$ & 0.043 & $\begin{array}{l}41.9 \\
(39.1-46.7)\end{array}$ & $\begin{array}{l}43.1 \\
(41.2-47.1)\end{array}$ & 0.047 & - & - \\
\hline W2-\% & $\begin{array}{l}12.3 \\
(9.2-15.1)\end{array}$ & 12 & $\begin{array}{l}12.7 \\
(10.6-13.7)\end{array}$ & $\begin{array}{l}11.6 \\
(9.5-17.6)\end{array}$ & - & $\begin{array}{l}12.5 \\
(7.8-15.1)\end{array}$ & $\begin{array}{l}11.9 \\
(9.4-15.8)\end{array}$ & - & - & - \\
\hline W3-\% & $\begin{array}{l}1.2 \\
(0-2.8)\end{array}$ & 0 & $\begin{array}{l}0.9 \\
(0-1.8)\end{array}$ & $\begin{array}{l}1.6 \\
(0-8.0)\end{array}$ & 0.049 & $\begin{array}{l}0 \\
(0-2.6)\end{array}$ & $\begin{array}{l}1.2 \\
(0-2.8)\end{array}$ & - & - & - \\
\hline $\begin{array}{l}\text { ACT- } \\
\mathrm{mg} / \mathrm{L}\end{array}$ & $\begin{array}{l}377 \\
(316-518)\end{array}$ & $350-450$ & $\begin{array}{l}476 \\
(406-602)\end{array}$ & $\begin{array}{l}370 \\
(290-468)\end{array}$ & 0.043 & $\begin{array}{l}334 \\
(315-504)\end{array}$ & $\begin{array}{l}399 \\
(338-580)\end{array}$ & 0.033 & 0.023 & 0.042 \\
\hline Al-\% & $\begin{array}{l}22.4 \\
(18.3-37.5)\end{array}$ & 25 & $\begin{array}{l}18.4 \\
(17.8-41.0)\end{array}$ & $\begin{array}{l}22.4 \\
(18.7-37.5)\end{array}$ & 0.041 & $\begin{array}{l}23.2 \\
(19.7-27.2)\end{array}$ & $\begin{array}{l}23.1 \\
(19.4-38.4)\end{array}$ & - & 0.039 & - \\
\hline A2-\% & $\begin{array}{l}29.7 \\
(26.0-38.5)\end{array}$ & 24 & $\begin{array}{l}28.0 \\
(26.2-38.5)\end{array}$ & $\begin{array}{l}29.5 \\
(25.3-36.6)\end{array}$ & - & $\begin{array}{l}31.0 \\
(29.1-38.5)\end{array}$ & $\begin{array}{l}28.5 \\
(25.6-39.8)\end{array}$ & - & - & - \\
\hline A3-\% & $\begin{array}{l}24.2 \\
(18.2-20.8)\end{array}$ & 26 & $\begin{array}{l}25.4 \\
(20.5-26.2)\end{array}$ & $\begin{array}{l}25.2 \\
(16.8-28.6)\end{array}$ & - & $\begin{array}{l}22.5 \\
(18.5-26.1)\end{array}$ & $\begin{array}{l}22.7 \\
(16.8-26.3)\end{array}$ & - & - & - \\
\hline A4-\% & $\begin{array}{l}14.5 \\
(4.3-20.9)\end{array}$ & 25 & $\begin{array}{l}20.3 \\
(4.2-22.7)\end{array}$ & $\begin{array}{l}14.8 \\
(3.0-21.0)\end{array}$ & 0.036 & $\begin{array}{l}3.8 \\
(9.3-16.7)\end{array}$ & \begin{tabular}{|l|}
14.1 \\
$(5.9-21.4)$
\end{tabular} & - & - & - \\
\hline A5-\% & $\begin{array}{l}3.9 \\
(0-7.1)\end{array}$ & 0 & $6.2(0-8.6)$ & $\begin{array}{l}3.9 \\
(0-6.8)\end{array}$ & - & $\begin{array}{l}4.2 \\
(0-10.3)\end{array}$ & $\begin{array}{l}0 \\
(0-6.6)\end{array}$ & 0.044 & - & - \\
\hline
\end{tabular}


Table 4. Coefficients of correlation (Rho, Spearman's test) between percentiles of particular EUROFIT elements and health parameters. Only statistically significant values are given $(p<0.05)$. WC - waist circumference, HC - hip circumference, WHR - waist-to-hip ratio, WHtR - waist-to height ratio.

\begin{tabular}{|c|c|c|c|c|c|c|c|c|c|}
\hline 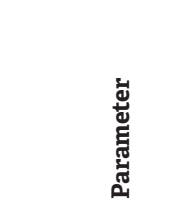 & 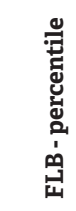 & 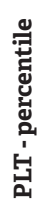 & 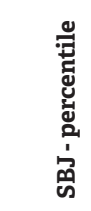 & 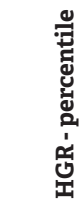 & 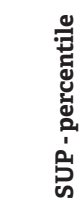 & 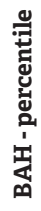 & 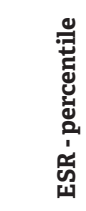 & 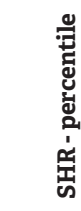 & 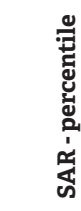 \\
\hline BMI (percentile) & & & -0.28 & 0.20 & -0.21 & & -0.22 & -0.21 & -0.27 \\
\hline WC & & & -0.33 & & -0.22 & & -0.24 & & -0.27 \\
\hline WHR & & & & & -0.20 & & -0.19 & & \\
\hline WHtR & & & -0.32 & & -0.19 & & -0.23 & -0.19 & -0.23 \\
\hline FAT\% & -0.23 & & & & & & & & \\
\hline LEAN\% & 0.23 & & & & & & & & \\
\hline WATER\% & 0.23 & & & & 0.20 & & & & \\
\hline
\end{tabular}

differences were observed in relation to cardio-respiratory endurence (median ESR $=9.0$ percentile for boys and 16.8 for girls, see Table 2).

Thus, the consequences of excessive fat mass are more severe for boys. The distribution of the fat tissue is probably of significance here. In boys it is usually located in the upper parts of the body and exhibits different biochemical properties. It can be concluded that obesity has more severe health consequences for boys than girls. On the other hand, the differences in the consequences of excessive body fat between the sexes have also been pointed out by Larsson et al. (2002), who reported a less negative impact of excessive body fat on the self-assessed quality of life of adult men than women. Perhaps, according to boys, obesity is less of a problem than for girls (Larsson et al., 2002).

Indicators of the distribution of fat in the study group (WHtR and WC) show the dominance of visceral fat distribution, which predisposes individuals for more serious health consequences. Focusing on improvement of cardiorespiratory fitness, but also muscular fitness and speed/agility, has been pointed out as a priority in promotional activities related to the reduction of abdominal adiposity, attenuate fatigue and improvement of quality of life of adolescents (Ortega et al., 2008).
In our study, worse results of SBJ, SHR and SAR fitness tests: flexibility, explosive strength, speed and agility indicate impairment not only of the motor element of fitness, but also of motor coordination. Similarly, worse results of the FLB test accompany a higher fat content and lower content of dry mass and water. This may indicate that metabolic activity of abdominal obesity also impairs psycho-physical coordination. Studies involving American youth show that the relationship between body fat and such motor skills as running speed and the strength of body muscles is curvilinear in boys, and rectilinear in girls (Pate et al., 1989).

Studies of acute phase proteins showed differences as regards the division by sex, and overweight or obesity due to the BMI percentile. The differences related to the concentration of AGP and the glycolysation profile of this protein for the subgroup with obesity may indicate greater metabolic activity of fat tissue located in the waist (increased production of interleukin 6), which is evidenced by literature data (Almuraikhy et al., 2016).

Currently, the rate of gaining weight by children and young people in Poland is the fastest in Europe (UNICEF Office of Research 2016). There are no current percentile charts and reference cutoff points 
for body composition indices. The charts by Stupnicki, available in the literature, differ significantly from virtually all of those developed for European children, and at the same time there is a lack of differences, for instance, as regards the BMI, which leads us to conclude that they need to be revised (Słupnicki, 2009). Our study also shows the lack of differentiation of adiposity percentiles for girls (all are classified above 97, according to the discussed reference values), given a situation where their BMI differs from overweight to obesity. Similarly, an important health predictor is the hydration status and the content of lean tissue, for which there are also no reference ranges.

The experience of other authors indicates that in clinical practice and in health promotion it is the measurement of WC and WHtR rather than BMI that should be taken into account with respect to the risk assessment of health complications as a screening instrument (Glasser et al., 2011). Further studies, possibly a cohort follow-up studies should be undertaken to provide exact prognostic value of both measurements.

\section{Conclusions}

The present findings demonstrate clearly that the BMI percentile, waist circumference and waist-to-height ratio increase, the results of fitness tests, measured using the EUROFIT test, deteriorate. The consequences of excessive body fat are greater for boys, both in terms of abnormal laboratory markers and physical fitness. The measurement of waist circumference and waist-to-height ratio rather than BMI should be taken into account with respect to the risk assessment of health complications in children and adolescents.

\section{REFERENCES}

Almuraikhy, S., Kafienah, W., Bashah, M., Diboun, I., Jaganjac, M., Al-Khelaif, F., et al. (2016), 'Interleukin-6 induces impairment in human subcutaneous adipogenesis in obesity-associated insulin resistance.' Diabetologia, 59, pp. 2406.

Altman, PL. (1961), 'Blood and Other Body Fluids. Washington', DC: Federation of American Societies for Experimental Biology.

Ben-Sefer, E., Ben- Natan, M., Ehrenfeld, M. (2009), 'Childhood obesity: current literature, policy and implications for practice.' Int nurs rev, 56, pp. 166-173.

Biro, F.M., Wien, M. (2010), 'Childhood obesity and adult morbidities.' AJCN, 91, pp. 1499-1505.

Bouchard, C., Shephard, RJ. (1994), 'Physical activity, fitness and health: The model and key concepts.' In C. Bouchard, R.J. Shephard, T. Stephens (eds.), 'Physical activity, fitness and health: International proceedings and consensus statement.' Champaign, IL: Human Kinetics Publishers, pp. 11-20.

Dobosz, J. (2012), ,Kondycja fizyczna dzieci i młodzieży w wieku szkolnym. Siatki centylowe". (In Polish). Akademia Wychowania Fizycznego w Warszawie, Warszawa.

El Hage, R., El Hage, Z., Jacob, C., Moussa, E., Theunynck, D., Baddoura, R.J. (2011), 'Bone mineral content and density in overweight and control adolescent boys.' Clin Densitom, 14, pp. 122-128.

Engeland, A., Bjorge, T., Tverdal, A., Sogaard, A.J. (2004), 'Obesity in adolescence and adulthood and the risk of adult mortality. Epidemiology', 15, pp. 79-85.

Gallagher, D., Heymsfield, S.B., Heo, M., Jebb, S.A., Murgatroyd, P.R., Sakamoto, Y. (2000), 'Healthy percentage body fat ranges: an approach for developing guidelines based on body mass index.' AJCN, 72, pp. 694-701. Glasser, H., Zellner, K., Kromeyer-Hauschild, K. (2011), 'Validity of body mass index and waist circumference to detect excess fat mass in children aged 7-14 years.' EJCN, 65, pp. 151-159.

Jakicic, J.M., Winters, C., Lang, W., Wing, R.R. (1999), 'Effects of intermittent exercise and use of home exercise equipment on adherence, weight loss, and fitness in overweight women: a randomized trial.' JAMA 27, 282, pp. 1554-1560. 
Kułaga, Z., Litwin, M., Zajączkowska, M.M., Wasilewska, A., Morawiec-Knysak, A., Różdżyńska, A. et al. (2008), 'Comparison of waist and hip circumferences ranges in children and adolescents in Poland 7-18 y of age with cardiovascular risk thresholds initial results of OLAF project (PL0080).' Stand Med 5, pp.473-485.

Lafortuna, C.L., Agosti, F., Marinone, P.G., Marazzi,N.,Sartorio,A.(2004), 'Therelationship between body composition and muscle power output in men and women with obesity.' J Endocrinol Invest, 27, pp. 854-861.

Lafortuna, C.L., Maffiuletti, N.A., Agosti, F., Sartorio, A. (2005), 'Gender variations of body composition, muscle strength and power output in morbid obesity.' Int J Obesity, 29, pp. 833-841.

Lamb, M.M., Ogden, C.L., Carroll, M.D., Lacher, D.A., Flegal, K.M. (2011), 'Association of body fat percentage with lipid concentrations in children and adolescents: United States, 1999-2004.' AJCN, 94, pp. 877-883. Larsson, U., Karlsson, J., Sullivan, M. (2002), 'Impact of overweight and obesity on healthrelated quality of life - a Swedish population study.' Int J Obes Relat Metab Disord 26, pp. 417-424.

Laurell, C.B. (1966), 'Quantitative estimation of proteins by electrophoresis in agarose gel containing antibodies.' Anal. Biochem 15, pp. 45-52.

Maciaszek, J. (2001), 'Relationship between muscular endurance of trunk and body fat in 10-14 year old girls.' Physical Education and Sport, 1, pp. 93-8.

Okorodudu, D.O., Jumean, M.F., Montori, V.M., Romero-Corral, A., Somers, V.K., Erwin P.J. et al. (2010), 'Diagnostic performance of body mass index to identify obesity as defined by body adiposity: a systematic review and meta-analysis.' Int J Obesity, 34, pp. 791-799. Ortega, F.B., Ruiz, J.R., Castillo, M.J., Sjöström, M. (2008), 'Physical fitness in childhood and adolescence: a powerful marker of health.' Int J Obesity, 32, pp. 1-11.

Pate, R.R., Slentz, C.A., Katz, D.P. (1989), 'Relationships between skinfold thickness and performance of health related fitness test items.' Res Q Exerc Sport, 2, pp. 183-189. Pawlaczyk, M., Sobieska, M., Wiktorowicz, K. (2001), 'Generalised inflammatory reaction present in plaque stage of mycosis fungoides.' Skin Cancer, 16, pp. 115-122.

Stupnicki, R. (2015), ,Relacje wagowo-wzrostowe i stosowanie wskaźnika BMI u dzieci i młodzieży". (In Polish). Zeszyty Naukowe WSKFiT 10, pp. 41-47.

Stupnicki, R., Tomaszewski, P., Milde, K., Czeczelewski, J., Lichota, M., Głogowska, J. (2009), 'Body fat-based weight norms for children and youths.' Pediatr Endocrinol Diabetes Metab, 15, pp. 139-143.

Tarnoki, A.D., Tarnoki, D.L., Medda, E., Cotichini, R., Stazi, M.A., Fagnani, C., et al. (2014), 'Bioimpedance analysis of body composition in an international twin cohort.' Obes Res Clin Pract, 3, pp. 291-297.

Tomkinson, G.R., Oldsb, T.S., Bormsc, J. (2007), 'Who Are the Eurofittest? Pediatric Fitness. Secular Trends and Geographic Variability.' Med Sport Sci, Basel, Karger, 50, pp. 104-128. Tompuri, T.T., Lakka, T.A., Hakulinen, M., Lindi, Virpi., Laaksonen, D.E., et al. (2015), Ass sessment of body composition by dual-energy $X$-ray absorptiometry, bioimpedance analysis and anthropometrics in children: the Physical Activity and Nutrition in Children study.' Clin Physiol Funct Imaging, 35, pp. 21-33.

UNICEF Office of Research. 'Child well-being in rich countries: a comparative overview'. Innocenti Report Card 11. Florence: UNICEF Office of Research, 2013. 